\title{
METODE PENGOLAHAN AIR LIMBAH DOMESTIK UNTUK PENURUNAN KADAR AMONIA: STUDI LITERATUR
}

\author{
Ni Luh Putu Intan Sintya Dewi, Ni Made Utami Dwipayanti \\ Program Studi Sarjana Kesehatan Masyarakat, Fakultas Kedokteran, Universitas Udayana \\ Alamat: Jalan PB. Sudirman, Denpasar, Bali 80232
}

\begin{abstract}
ABSTRAK
Pertumbuhan jumlah penduduk yang semakin pesat dan diiringi dengan semakin merebaknya permukiman akan berpengaruh terhadap jumlah buangan limbah cair yang ditimbulkan oleh aktifitas dalam rumah tangga. Denpasar Sewerage Development Project (DSDP) Tahap I dan Tahap II atau pembangunan prasarana air limbah Denpasar memiliki tujuan untuk mengatasi permasalahan pencemaran lingkungan dan sanitasi di Denpasar dan sekitarnya. Pengolahan limbah yang dilakukan oleh DSDP belum efektif terhadap pengolahan amonia. Penelitian ini dilakukan dengan tujuan untuk mengetahui alternatif metode pengolahan limbah domestik yang efektif terhadap penurunan amonia berdasarkan hasil penelitian yang telah dilakukan selama satu dekade terakhir. Desain penelitian ini adalah Literature Review atau tinjauan pustaka dengan sumber data yang didapatkan dari media internet yang kemudian data disintesis menggunakan metode naratif dengan mengelompokkan data hasil ekstraksi yang sejenis sesuai dengan hasil yang diukur untuk menjawab tujuan penelitian. Hasil dari penelitian ini ditemukan empat jenis metode pengolahan limbah domestik berdasarkan hasil dari Literature Review yaitu metode pengolahan dengan constructed wetland, lumpur aktif, biofilter, dan pengolahan dengan metode kimiawi.
\end{abstract}

Kata kunci: Limbah Domestik, Pencemaran Lingkungan, Sistem Pengolahan Limbah, Efektivitas, Amonia

\begin{abstract}
The high number of population growth and increased number of settlements can influences the amount of liquid waste discharged from household activities. Denpasar Sewerage Development Project (DSDP) part I and part II or the infrastructure development programs wich has a purpose to resolve the environmental pollution and sanitation problems in around Denpasar (Putera, dkk, 2019). Wastewater management that wich conducted by DSDP it is not effective towards ammonia removal. The aim of this research to find out alternative methods of domestic waste management that are effective against ammonia reduction based on the results of research that has been conducted over the past decade. The design of this study is Literature Review, data sources obtained from internet, then the data is synthesized using a narrative method by grouping data extraction results of the same type in accordance with the measured results to answer the aims of this research. The results of this study have been found four types of domestic waste water treatment methods based on the results of the Literature Review, the method is constructed wetland, activated sludge, biofilter, and chemical treatment methods.
\end{abstract}

Keywords: Domestic Waste, Environmental Pollution, Sewage Treatment Systems, Effectiveness, Ammonia

\section{PENDAHULUAN}

Bali memiliki sarana pengolahan air limbah di daerah IPAL Suwung, dengan proyeknya yang dikenal dengan DSDP. Denpasar Sewerage Development Project (DSDP) Tahap I dan Tahap II atau pembangunan prasarana air limbah Denpasar memiliki tujuan untuk mengatasi permasalahan pencemaran lingkungan dan sanitasi di Denpasar dan sekitarnya (Putera et al., 2019). Penelitian Rarasari.,et.al. (2019) menunjukkan bahwa kegiatan pengolahaan limbah di IPAL Suwung tidak efektif terhadap pengurangan amonia dikarenakan hasil pengolahan terhadap amonia masih berkisar 19,50 mg/L, serta DO (Dissolve Oxygen) yang tidak memenuhi baku mutu. Amonia yang tinggi akan berpengaruh terhadap kehidupan ekosistem yang ada di laut. Amonia total 
pada lingkungan memiliki baku mutu sebesar $10 \mathrm{mg} / \mathrm{L}$, bila melebihi kadar tersebut dapat bersifat toksik bagi beberapa jenis ikan dan biota laut (Sihaloho, 2009). Konsentrasi $\mathrm{NH}_{3}$ bebas yang tinggi di perairan dapat menyebabkan kerusakan insang pada ikan, tingginya konsentrasi $\mathrm{NH}_{3}$ bebas dapat menyebabkan meningkatnya kadar amonia dalam darah dan jaringan tubuh ikan, sehingga dapat mengurangi kemampuan darah untuk mengangkut oksigen serta mengganggu kestabilan membran sel (Suparno, 2016).

Amonia memiliki senyawa unsur nitrat di dalamnya bila melebihi baku mutu akan meningkatkan terjadinya eutrofikasi (pengayaan) perairan dan selanjutnya menstimulir pertumbuhan alga dan tumbuhan air secara pesat (Hamuna et al., 2018). Semakin tingginya kandungan amonia dalam perairan maka akan bersifat toksik dan korosif dimana akan berdampak buruk bagi pengguna air (Yasser et al., 2008). Sebgai langkah awal untuk menyelesaikan masalah kandungan amonia dalam efluent IPAL suwung adalah melakukan kajian pustaka mengenai upayaupaya pengurangan amonia pada air limbah domestik. Dari kajian pustaka tersebut diharapkan dapat memberikan masukan mengenai alternative terbaik kepada IPAL Suwung dalam menyelesaikan masalah tersebut sehingga dapat meningkatkan efektivitas penurunan amonia pada efluentnya. Tujuan dalam penelitian ini adalah untuk mengetahui alternatif metode pengolahan limbah domestik yang efektif terhadap penurunan amonia berdasarkan hasil penelitian yang telah dilakukan selama satu dekade terakhir.

\section{METODE PENELITIAN}

1) Desain penelitian

Desain penelitian ini adalah Literature Review atau tinjauan pustaka. Studi literature review adalah cara yang dipakai untuk mengumpulkan data atau sumber yang berhubungan dengan sebuah topik tertentu yang sumbernya dapat diperoleh dari jurnal,buku, internet, dan pustaka lain. Dalam penelitian ini sumber yang dipergunakan merupakan jurnal dan artikel yang diunduh melalui internet yang memiliki jangka waktu sepuluh tahun terakhir.

2) Sumber Data

Sumber data yang dipergunakan dalam penelitian ini adalah artikel penelitian yang didapatkan dari Neliti.com, Google Scholar, Research Gate, Portal Garuda,dan Academia.edu. Desain penelitian yang diambil dalam penelusuran ilmiah adalah penelitian yang menggunakan metode penelitian eksperimen, analisis korelasi, analisis komparasi, dan kualitatif studi. Intervensi utama yang ditelaah pada penelusuran ilmiah ini adalah metode pengolahan limbah domestik yang bertujuan untuk menurunkan kandungan amonia. Outcome yang di ukur dalam penelusuran ilmiah ini adalah metode pengolahan limbah domestik yang memiliki efektivitas dan efisiensi diatas atau sama dengan 50\% terhadap penurunan amonia pada hasil efluentnya. 
3) Kriteria Inklusi

Artikel atau jurnal yang sesuai dengan kriteria inklusi dan ekslusi diambil untuk selanjutnya dianalisis. Literature Review ini menggunakan literatur terbitan tahun 2010 - 2020 yang dapat diakses fulltext dalam format pdf. Kriteria jurnal yang di-review adalah artikel jurnal penelitian berbahasa Indonesia dan berbahasa Inggris dengan subyek penurunan amonia tidak termasuk jurnal literatur review. Jurnal yang sesuai dengan kriteria inklusi dan terdapat tema pengolahan limbah domestik, pengolahan limbah domestik yang yang efektif terhadap penurunan amonia, pengolahan limbah domestik dengan biaya yang murah kemudian dilakukan review.Kriteria inklusi penelitian yang dipergunakan dapat dilihat pada tabel 1.

Tabel 1. Kriteria Inklusi Penelitian

Kriteria Inklusi

Jangka Waktu Rentang waktu penerbitan maksimal 10 tahun (2010 - 2020)

Bahasa Bahasa Indonesia dan Bahasa Inggris

Subyek Penurunan amonia

Jenis Jurnal Original artikel penelitian (bukan review penelitian)

Tema isi jurnal Pengolahan limbah domestik yang efektif menurunkan kandungan

amonia.

4) Penilaian Kualitas Artikel

Penilaian kualitas artikel dilakukan dengan menggunakan telaah kritis (Critical Appraisal) berdasarkan milik The Joanna Briggs Institute (JBI) critical apprasial checklist tool for quasi-experimental studies (nonrandomized experimental studies) terdapat 9 poin pertanyaan, karena dalam penelitian ini tidak menggunakan meta analisis karena variasinya terlalu besar dan tidak menjelaskan review mengenai studi kualitatif yang dilakukan peneliti pada jurnal. Terdapat empat pilihan yakni yes, No, Unclear, and Not Applicable. Besaran Penilaian JBI berdasarkan bobot poin-poin adalah sebagai berikut: Kualitas kurang (13); Kualitas cukup (4-6); Kualitas Baik (7-9). Penilaian kualitas artikel dapat dilihat pada lampiran 1. 
HASIL

Karakteristik Umum Artikel yang direview

Terdapat lima belas Artikel yang sesuai dengan kriteria inklusi. Artikel penelitian yang didapat merupakan artikel yang yang diterbitkan di Indonesia (dominan), Iran, Australia, dan Polandia. Artikel tersebut merupakan artikel terbitan tahun 2010 sampai dengan tahun 2019. Penelitiannya merupakan penelitian eksperimental terkait dengan metode pengolahan limbah domestik. Metode pengolahan limbah pada penelitian tersebut kebanyakan menggunakan pengolahan limbah secara biologis dan kimia, seperti fitoremediasi, lumpur aktif, biofilter,penambahan senyawa kimia berupa klorin polymer hydrogels. Efisiensi hasil pengolahan terhadap penyisihan amonia memiliki efisiensi diatas 50\%. Alur prosedur proses seleksi artikel dapat dilihat pada Gambar 1.

Efisiensi Penyisihan Amonia Berdasarkan Kelompok Pengolahan

Adapun hasil penelitian yang didapatkan berdasarkan hasil review artikel dapat dilihat pada lampiran 2 yang telah dikelompokkan berdasarkan metode pengolahannya. Berdasarkan penelusuran artikel yang telah dilakukan, terdapat lima belas artikel yang memenuhi kriteria inklusi. Lima belas artikel yang telah sesuai dengan kriteria inklusi didapatkan berbagai hasil penelitian terkait dengan metode pengolahan limbah untuk penurunan amonia dalam limbah domestik. Metode pengolahan limbah dengan constructed wetland diteliti oleh (Lestari, 2012), (Romadhony \& Sutrisno, 2013), (Asela \& Astuti, 2016), (Hidayah et al,. 2018), (Imron et al., 2019), dan (Peng et al., 2013). Metode pengolahan limbah dengan metode lumpur aktif diteliti oleh (Nourmohammadi et al., 2013), dan (Smyk \& Ignatowicz, 2017). Metode pengolahan limbah dengan biofilm (biofilter) diteliti oleh (Sarasdewi et al., 2015), (Hibban et al., 2016), (Ningtias et al., 2018), dan (Adisuasono et al., 2014) dan (Faisal, Machdar et al., 2017). Metode pengolahan limbah secara kimia diteliti oleh (Cruz et al., 2018) dan (Maria \& Affan, 2017). Jumlah artikel berdasarkan kelompok metode pengolahan dapat dilihat pada gambar 2 .

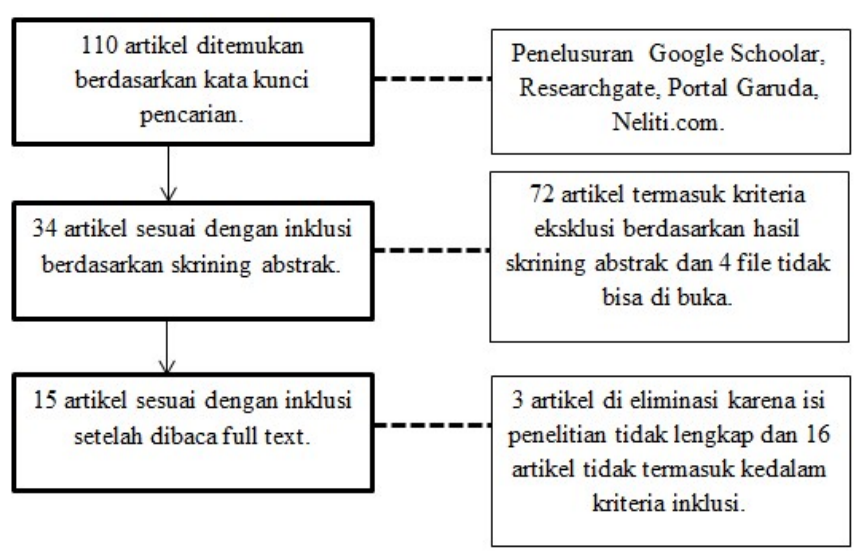

Gambar 1. Alur Prosedur Proses Seleksi Artikel 


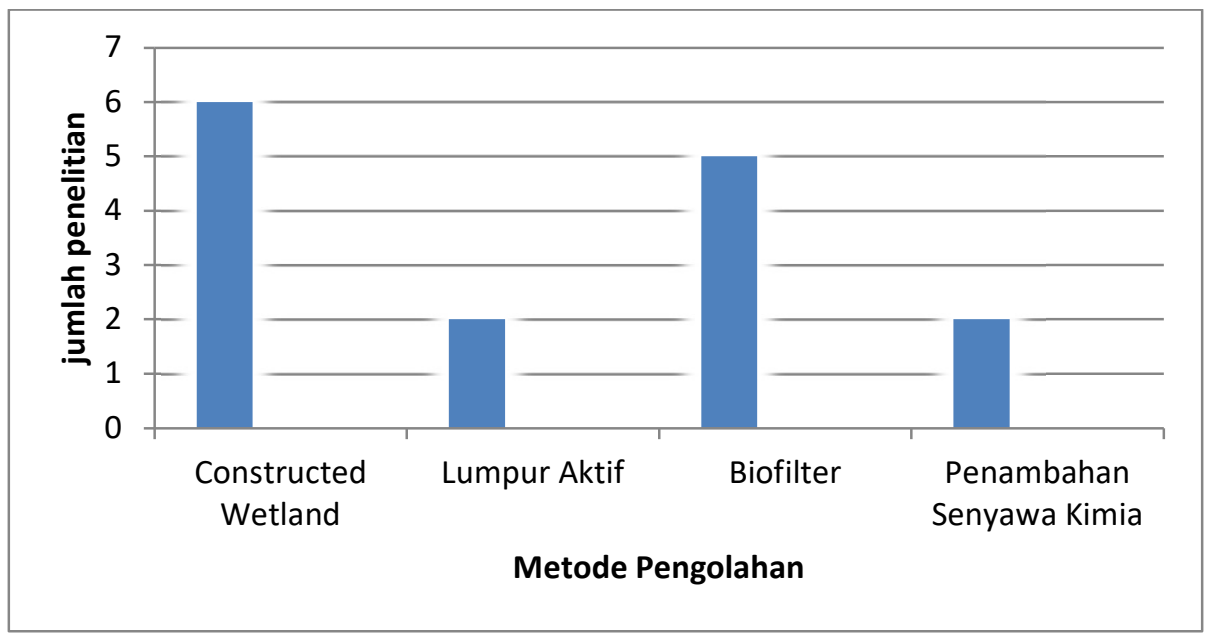

\section{Gambar 2. Jumlah Artikel Penelitian yang Di-review}

Pada Gambar 2 menunjukkan jumlah artikel penelitian yang didapatkan berdasarkan hasil review sebanyak enam artikel yang melakukan penelitian dengan metode Constructed wetland, dua penelitian yang menggunakan metode lumpur aktif, lima penelitian yang menggunakan metode biofilter, dan dua penelitian yang melakukan penambahan senyawa kimia.

\section{Efisiensi Setiap Metode Pengolahan}

Efisiensi pengolahan limbah terhadap penyisihan amonia dapat dilihat pada gambar 3. Gambar 3 menunjukkan gambaran efisiensi pada setiap metode pengolahan limbah berdasarkan jumlah artikel penelitian yang didapatkan. Dapat dilihat bahwa efisiensi tertinggi terdapat pada metode pengolahan dengan constructed wetland dengan nilai efisiensi > 95\% terdapat didalam hasil penelitian lima buah artikel dari enam artikel yang direview. Dapat dilihat juga data hasil efisiensi yang variatif terdapat dalam metode pengolahan dengan biofilter, setiap penelitiannya memiliki hasil efisiensi yang berbeda-beda.

Konsentrasi Inlet, Outlet, dan Loading Rate Amonia

Konsentrasi inlet pada setiap metode pengolahan dapat dilihat pada tabel 2 . Tabel 2 menunjukkan rentangan konsentrasi inlet pada setiap metode pengolahan berdasarkan jumlah artikel penelitian yang di review. Pada tabel, konsentrasi inlet amonia yang variatif terdapat pada penelitian dengan metode constructed wetland. Tabel 2 menunjukkan konsnetrasi inlet minimal terdapat pada metode pengolahan constructed wetland pada salah satu artikel penelitian yang direview yaitu dengan konsentrasi inlet sebesar 0,45 mg/l dan konsentrasi inlet amonia tertinggi terdapat dalam metode pengolahan dengan biofilter sebesar 98,43 $\mathrm{mg} / \mathrm{l}$. 


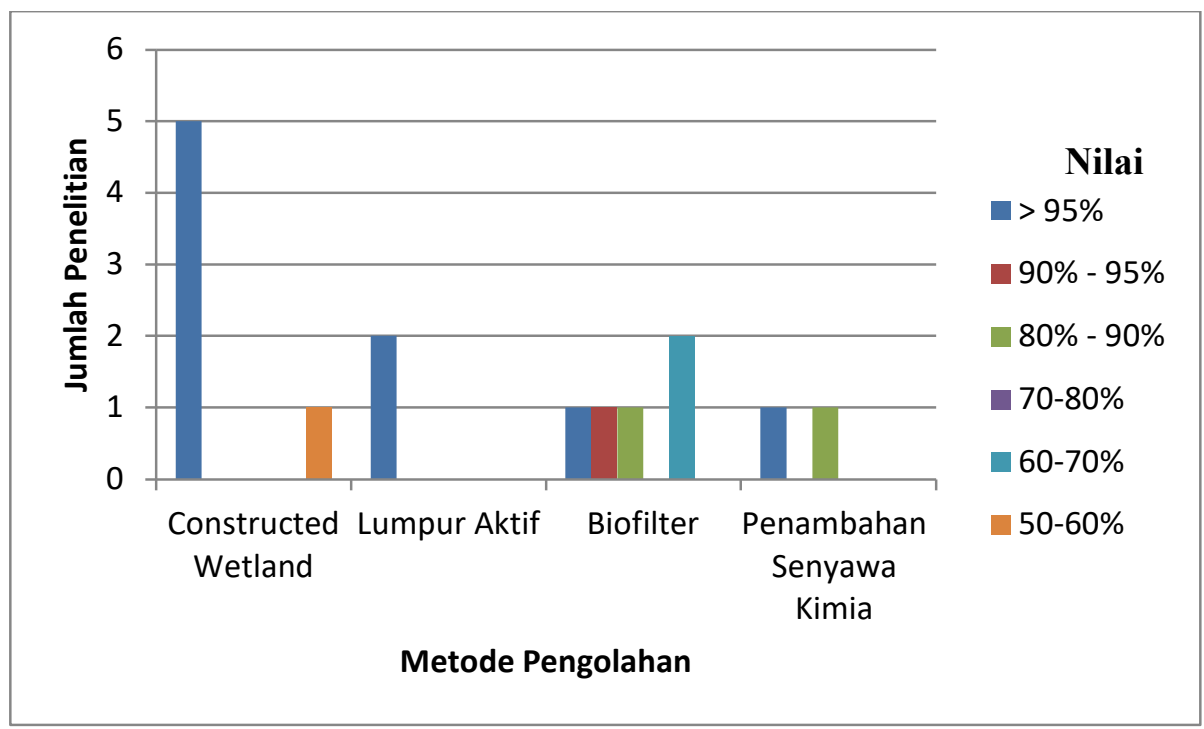

Gambar 3. Rentangan Efisiensi pada Setiap Metode Pengolahan

Tabel 2. Konsentrasi Inlet Amonia pada Setiap Metode Pengolahan

\begin{tabular}{lcc}
\hline \multicolumn{1}{c}{ Metode Pengolahan } & $\begin{array}{c}\text { Rentangan Konsentrasi } \\
\text { Inlet Amonia (mg/l) }\end{array}$ & $\begin{array}{c}\text { Rata-rata konsentrasi inlet amonia } \\
(\mathbf{m g} / \mathbf{l})\end{array}$ \\
\hline Constructed Wetland & $0,45-43,83$ & 10,09 \\
\hline Lumpur Aktif & $26,8-51,1$ & 38,95 \\
\hline Biofilter & $18,19-98,43$ & 35,93 \\
\hline $\begin{array}{l}\text { Pengolahan dengan } \\
\text { senyawa kimiawi }\end{array}$ & $22,66-50$ & 36,33 \\
\hline
\end{tabular}

Loading rate yang ditemukan pada hasil review dapat dilihat pada lampiran 8 . Data loading rate pada setiap artikel yang direview, dapat dilihat bahwa loading rate yang tertinggi terdapat pada metode pengolahan biofilter yaitu sebesar 290 $\mathrm{mg} /$ hari dan loading rate terendah terdapat dalam metode pengolahan constructed wetland yaitu sebesar 0,23 mg/hari.

Faktor-Faktor yang Mempengaruhi Kinerja Pengolahan Limbah

\section{Constructed Wetland}

Faktor yang mempengaruhi pengolahan limbah dengan menggunakan sistem pengolahan constructed wetland berdasarkan hasil review dapat dilihat dalam lampiran 3. Faktor yang mempengaruhi adalah suhu, $\mathrm{pH}$, proses aklimatisasi, mikroorganisme, HRT, jenis tanaman air, dan media tumbuh.

\section{Lumpur Aktif}

Faktor yang mempengaruhi pengolahan limbah dengan menggunakan sistem pengolahan lumpur aktif berdasarkan hasil review dapat dilihat dalam lampiran 4 . Faktor yang mempengaruhi adalah suhu, $\mathrm{pH}$, mikroorganisme, HRT, aerasi, SRT, dan ratio $\mathrm{C} / \mathrm{N}$. 


\section{Biofilter}

Faktor yang mempengaruhi pengolahan limbah dengan menggunakan sistem pengolahan biofilter berdasarkan hasil review dapat dilihat dalam tabel lampiran 5 . Faktor yang mempengaruhi adalah suhu, $\mathrm{pH}$, mikroorganisme, aklimatisasi, HRT, laju aliran, dan media.

\section{Proses Pengolahan Secara Kimiawi}

Faktor yang mempengaruhi pengolahan limbah dengan menggunakan sistem pengolahan secara kimiawi berdasarkan hasil review dapat dilihat dalam lampiran 6. Faktor yang mempengaruhi adalah suhu, $\mathrm{pH}$, dan konsentrasi zat kimia yang dipergunakan.

\section{DISKUSI}

\section{Constructed Wetland}

\section{a) Proses Penyisihan Amonia}

Constructed Wetland adalah salah satu rekayasa sistem pengolahan limbah yang dirancang dan dibangun dengan melibatkan tanaman air, tanah atau media lain, dan kumpulan mikroba terkait (Greg et al., 1998 dalam Suswati \& Wibisono, 2013). Jenis tanaman air yang dipergunakan merupakan tanaman air yang memiliki kemampuan untuk menyerap zat pencemar yang terdapat dalam air limbah. Selain berfungsi sebagai penyerapan zat pencemar, tanaman juga berfungsi sebagai tempat untuk menempelnya mikroorganisme dan sebagai pemasok oksigen untuk kelangsungan hidup bakteri. Tanaman air yang dominan dipergunakan padaartikel yang di-review adalah eceng gondok. Selain kemampuan eceng gondok terhadap penyerapan zat pencemar, akar tanaman ini merupakan tempat menempelnya mikroorganisme pengurai dan juga memiliki kemampuan sebagai pemasok oksigen melalui rizofer yang dapat mendukung pertumbuhan bakteri aerob yang mendegradasiamonia dalam sistem pengolahan (Romadhony \& Sutrisno, 2013).

Substrat/media berperan sebagai tempat menempelnya mikroorganisme sehingga memperluah permukaan sistem rawa buatan. Selain itu substrat juga berperan untuk menyokong tumbuhan air, membantu proses filtrasi (terutama pada rawa buatan beraliran bawah permukaan / sub surface flow), dan menampung sedimen. Jenis substrat sangat mempengaruhi waktu detensi, oleh karena itu pemilihan substrat yang tepat sangat menentukan keberhasilan sistem dalam mengolah air limbah (Puspita et al., 2005).

Bakteri yang dipergunakan dalam proses penyisihan amonia pada sistem adalah bakteri nitrifikasi. Bakteri nitrifikasi memiliki peranan dalam perombakan amonia, hal tersebut dikarenakan bakteri nitrifikasi mampu merombak amonia menjadi senyawa nitrit dan nitrat (Hastuti, 2011). Proses nitrifikasi masuk kedalam siklus biogeokimia nitrogen yang terdiri dari amonifikasi, nitirifikasi, asimilasi nitrogen, denitrifikasi, dan fiksasi. Nitrifikasi merupakan reaksi oksidasi yaitu proses pembentukan nitrit atau nitrat dari senyawa amonia, proses ini dapat berlangsung secara biologis dengan bantuan bakteri (Hastuti, 2011). 
Selain mengalami proses nitrifikasi atau perombakan oleh bakteri, penurunan kadar $\mathrm{NH}_{3}$ pada proses pengolahan dapat terjadi karena adanya proses volatilisasi. Proses volatilisasi terjadi karena adanya proses penghilangan kadar amonia yang merupakan proses penguraian secara fisika. Proses penguraian amonia secara fisika dapat terjadi karena adanya perubahan wujud dari senyawa amonia yang berada di dalam air limbah menguap ke atmosfer. Hal tersebut dapat terjadi karena adanya peningkatan $\mathrm{pH}$ pada air limbah, sehingga dapat menimbulkan atau meningkatkan alkalinitas pada limbah dan dapat menimbulkan terjadinya pelepasan gas $\mathrm{NH}_{3}$ ke udara (Saeed \& Sun, 2012). Volatilisasi amonia pada umumnya tidak terjadi pada subsurface flow wetlands (wetland beraliran bawah) bila $\mathrm{pH}$-nya berada pada rentang 7,5 - 8,0 (Reddy et al., 1984).

Konsentrasi dan loading rate amonia yang tinggi berpengaruh terhadap kehidupan mikroorganisme yang ada pada mikroorganisme dalam reaktor (Liu, Et al dalam Pertiwi \& Handajani, 2012). Hal tersebut dikarenakan bakteri belum beradaptasi dengan lingkungan yang baru. Laju aliran atau debit juga mempengaruhi kinerja reaktor seperti yang dijelaskan Sy et al. (2017) bahwa semakin besar laju aliran pada suatu reaktor semakin rendah efisiensi penguraian terhadap senyawa organik. Teori ini dibuktikan oleh Sarasdewi et al. (2015) yang mengujikan pengaruh laju aliran air limbah dalam reaktor yang mendapatkan hasil efisiensi penyisihan amonia yang terbaik terdapat pada laju aliran yang paling rendah.

Faktor yang juga memiliki pengaruh terhadap efisiensi pengolahan. Penelitian Lestari (2012), Romadhony \& Sutrisno (2013), Asela et al. (2016), Hidayah et al. (2018), Imron et al. (2019), Peng et al. (2013) melakukan tahapan aklimatisasi secara kontinyu dalam reaktor sebelum melakukan proses percobaannya. Aklimatisasi merupakan proses pengadaptasian mikroorganisme terhadap air limbah yang akan diolah (Said \& Utomo, 2018). Selain itu suhu dan $\mathrm{pH}$ pengolahan juga diperhatikan selama proses pengolahan. Suhu yang dipergunakan ratarata berkisar antara $23^{\circ} \mathrm{C}-30^{\circ} \mathrm{C}$ dan $\mathrm{pH}$ yang dipergunakan berkisar antara 6,5-7,5. Pada perairan, persentasi amonia bebas akan mengalami peningkatan seiring dengan peningkatan suhu dan $\mathrm{pH}$. Pada $\mathrm{pH}$ tinggi, amonia terdapat dalam jumlah yang lebih banyak. Sebaliknya jika $\mathrm{pH}$ rendah, nilai amonia akan lebih sedikit. Sedangkan pengaruh suhu pada penyisihan amonia bila suhu semakin tinggi maka akan menimbulkan banyaknya amonia dalam perairan. Hal sebaliknya dapat terjadi bila suhu menurun, maka jumlah amonia akan menurun dikarenakan amonia terionisasi menjadi senyawa nitrogen lainnya (Effendi, 2003 dalam Pribadi et al., 2016).

Selain untuk penyisihan amonia, peranan $\mathrm{pH}$ dan suhu juga memiliki peran terhadap pertumbuhan bakteri pada pengolahan biologis. PH yang baik terhadap pertumbuhan bakteri pendagradasi adalah pada $\mathrm{pH}$ optimum 7,5 
- 8,5 (Hibban, 2016 dalam Pribadi et al., 2016). Sedangkan untuk aktivitas mikroorganisme pengurai biasanya terjadi dalam suhu yang hangat atau berada pada rentangan suhu optimum yang berkisar $20^{\circ} \mathrm{C}-30^{\circ} \mathrm{C}$ (Effendi, 2003 dalam Pribadi ett al., 2016).

Penelitian yang menggunakan pengaturan waktu terhadap HRT adalah penelitian dari Romadhony \& Sutrisno (2013) dan Hidayah et al. (2018) yang menguji pengaruh HRT terhadap efisiensi pengolahan limbah dan penyisihan amonia. Pada penelitian tersebut didapatkan efisiensi tertinggi terhadap penyisihan amonia dan pengloahan limbah terdapat pada HRT dengan waktu yang paling lama. Waktu tinggal limbah dalam reaktor dalam waktu yang lama dapat memberikan kesempatan bagi reaktor untuk bekerja lebih optimum (Hibban et al., 2016). Menurut Zafarzadeh et al. (2010) dalam Ningtias et al. (2018) proses degradasi polutan dalam air limbah dengan memanfaatkan pertumbuhan mikroorganisme memerlukan waktu tinggal sebagai kesempatan untuk kontak antara mikroorganisme pengurai dengan air limbah. Sehingga dengan waktu kontak yang lebih lama, mikroorganisme dapat bekerja dengan optimum.

b) Kelebihan dan Kekurangan Pengolahan Constructed Wetland

Kelebihan dari pengolahan limbah dengan metode Constructed Wetland berdasarkan hasil review adalah pengolahan jenis ini memiliki biaya yang murah, mudah dilakukan serta memiliki efisiensi terhadap penyisihan amonia dan kandungan organik lainnya dalam limbah (Lestari, 2012), (Romadhony \& Sutrisno, 2013), (Asela \& Astusi, 2016), (Imron et al., 2019). Hal yang serupa juga disebutkan dalam buku Puspita et al. (2005) yang menerangkan bahwa constructed wetland memiliki biaya pembangunan dan biaya operasionalnya relatif lebih murah bila dibandingkan dengan sistem pengolahan air limbah lainnya, sehingga constructed wetland dapat dipergunakan sebagai sistem alternatif pengolahan air limbah di negara berkembang (Puspita et al., 2005).

\section{Lumpur Aktif}

a) Proses Penyisihan Amonia

Proses penyisihan amonia pada penelitian Nourmohammadi et al. (2013) dan Smyk \& Ignatowiczs (2017) melakukan penelitian dengan metode pengolahan dengan sistem lumpur aktif. Pengolahan dengan metode lumpur aktif memanfaatkan mikroorganisme yang terlarut atau tersuspensi didalam air limbah, sehingga menggunakan reaktor suspended Growth untuk pengujiannya. Reaktor pertumbuhan tersuspensi (Suspended Growth reactor) merupakan reaktor yang memanfaatkan mikroorganisme yang berperan pada proses biologis tumbuh dan berkembangbiak dalam keadaan tersuspensi (Titiresmi, 2011).

Proses penguraian amonia pada penelitian Nourmohammadi et al. (2013) dan Smyk \& Ignatowicz (2017) dilakukan oleh mikroorganisme atau bakteri yang memiliki kemampuan oleh mikroorganisme 
yang mampu mendegradasi senyawa amonia dalam air limbah. Proses perombakan amonia disebut dengan proses nitrifikasi yang dilakukan oleh bakteri Nitrosamonas dan Nitrobacter. Bakteri Nitrosamonas dan Nitrobacter merupakan jenis dari bakteri nitrifikasi dengan morfologi yang sama yaitu berbentuk bulat, tepian/tekstur licin, elevasi cembung, akan tetapi terdapat perbedaan warna Nitrosamonas berwarna putih dan Nitrobacter berwarna kuning (Kiding et al., 2015). Kedua bakteri tersebut termasuk golongan bakteri heterotrof. Bakteri heterotrof adalah bakteri yang hidup dengan mendapat makanan dari zat organik dari lingkungan karena tidak dapat menyusun sendiri zat organik yang dibutuhkannya (Notowinarto \& Agustina, 2015).

Untuk mendukung proses biologis dalam pengolahan air limbah Smyk \& Ignatowicz (2017) memberikan penambahan molase sebagai tambahan karbon eksternal sebagai upaya untuk menyeimbangkan ratio $\mathrm{C} / \mathrm{N}$ dalam air limbah. Hal ini dijelaskan oleh Sperling \& Chernicharo, (2005) parameter praktis juga perlu diperhatikan dalam lumpur aktif mengingat lumpur aktif menggunakan bakteri sebagai bahan pengurai. Parameter praktis yang dimaksudkan adalah rasio makanan per mikroorganisme (rasio $\mathrm{F} / \mathrm{M}$ ), yang didefinisikan sebagai beban makanan atau substrat (BOD) yang disediakan per hari untuk satu unit biomassa di reaktor.

Pengolahan limbah dengan metode lumpur aktif tidak terlepas dari proses aerasi. Seperti yang terdapat dalam penelitian Nourmohammadi et al. (2013) dan Smyk \& Ignatowiczs, (2017). Proses aerasi dimanfaatkan sebagai proses pengadukan antara air limbah dengan lumpur serta sebagai tambahan oksigen untuk kelangsungan hidup bakteri aerob yang memiliki peranan dalam proses degradasi senyawa amonia dalam air limbah. Sperling \& Chernicharo (2005) menjelaskan bahwa penambahan waktu aerasi dapat memperpanjang umur lumpur, sehingga bakteri dapat hidup lebih lama dan maksimal dalam proses penguraian.

Solid Retention Time

(SRT) merupakan suatu poin kritis yang terdapat didalam sistem pengolahan lumpur aktif yang mempengaruhi kinerja dari sistem pengolahan. SRT merupakan waktu yang dihabiskan oleh mikroorganisme dalam sistem pengolahan atau dapat juga disebut dengan waktu retensi rata-rata (MCRT) atau usia lumpur (Smith et al., 2013). Faktor lainnya yang mempengaruhi kinerja reaktor adalah suhu dan $\mathrm{pH}$. Nourmohammadi et al. (2013) dan Smyk \& Ignatowichz (2017) mempertahankan suhu dan $\mathrm{pH}$ yang optimum untuk pertumbuhan bakteri. Sehingga, bakteri atau mikroorganisme dapat hidup dengan nyaman dan dapat melakukan proses pengolahan secara maksimal. Konsentrasi inlet dan loading rate yang tinggi berpengaruh terhadap kehidupan mikroorganisme yang ada pada mikroorganisme dalam reaktor (Liu, Et al dalam Pertiwi \& Handajani, 2012). Laju aliran atau debit juga mempengaruhi kinerja reaktor seperti yang dijelaskan Sy et 
al. (2017) bahwa semakin besar laju aliran pada suatu reaktor semakin rendah efisiensi penguraian terhadap senyawa organik.

b) Kelebihan dan Kekurangan Proses Lumpur Aktif

Berdasarkan hasil literatur review penelitian dari Nourmohammadi et al. (2013) dan Smyk \& Ignatowichz (2017) memiliki kelebihan yaitu penelitian Nourmohammadi et al. (2013) memiliki kelebihan dari efisiensi penyisihan amonia yang tinggi mecapai angka $\geq 90 \%$ begitu juga dengan Smyk \& Ignatowichz (2017). Kekurangan dari proses lumpur aktif berdasarkan hasil literatur review biaya operasional yang tinggi dikarenakan menggunakan energi listrik untuk proses aerasi, perawatan yang sulit sehingga diperlukan tenaga ahli, harus sering melakukan pengurasan lumpur mengingat usia lumpur untuk kelancaran proses dekomposisi.

\section{Biofilter}

\section{a) Proses Penyisihan Amonia}

Biofilter atau biofilm merupakan sistem pengolahan air limbah dengan memanfaatkan mikroorganisme yang tumbuh dan berkembang terlekat secara biologi (Sormin, 2018). Penelitian dari Sarasdewi et al. (2015), Hibban et al. (2016), Ningtias et al. (2015), Adisuasono et al. (2014), Faisal et al. (2017) melakukan penelitian dengan menggunakan metode pengolahan secara biofilter yang merupakan reaktor dengan pertumbuhan bakteri dengan media terlekat. Reaktor pertumbuhan lekat (attached growth reactor), merupakan reaktor yang mikroorganismenya tumbuh dan berkembang diatas suatu media (support) dengan membentuk suatu lapisan lendir untuk melekatkan diri diatas permukaan media tersebut dan membentuk lapisan biofilm (Metcalf \& Eddy dalam Titiresmi, 2011).

Bakteri yang memiliki peranan dalam proses penyisihan amonia adalah bakteri (Nitrosomonas sp) dan (Nitrobacter $s p$ ) seperti yang tercantum dalam penelitian Sarasdewi et al. (2015), Hibban et al. (2016), Adisuasono et al. (2014). Bakteri Nitrosamonas dan Nitrobacter merupakan jenis dari bakteri nitrifikasi. Hidraulic Retention Time (HRT) terhadap efisiensi penyisihan amonia ditemukan pada penelitian Hibban et al. (2016), Ningtias et al. (2015), dan Adisuasono et al. (2014). Variasi terhadap waktu tinggal (HRT) dilakukan oleh ketiga penelitian tersebut dengan memvariasikan dari waktu yang paling singkat hingga waktu yang paling lama. Efisiensi tertinggi dari pengaruh HRT terhadap penyisihan amonia terdapat pada HRT yang paling lama. Hal tersebut dapat terjadi karena HRT atau waktu tinggal limbah dalam reaktor dalam waktu yang lama dapat memberikan kesempatan bagi reaktor untuk bekerja lebih optimum (Hibban et al., 2016).

Laju aliran limbah atau debit air juga memiliki pengaruh kinerja reaktor seperti yang dijelaskan Sy et al. (2017) bahwa semakin besar laju aliran pada suatu reaktor semakin rendah efisiensi penguraian terhadap senyawa organik. Teori ini dibuktikan oleh Sarasdewi et al. (2015) yang 
mengujikan pengaruh laju aliran air limbah dalam reaktor yang mendapatkan hasil efisiensi penyisihan amonia yang terbaik terdapat pada laju aliran yang paling rendah.

Selain itu beberapa faktor yang telah dijelaskan, berdasarkan hasil review semua penelitian yang terkait dengan pengolahan biofilter menggunakan suhu optimum pada pertumbuhan bakteri. PH yang baik terhadap pertumbuhan bakteri pendagradasi adalah pada $\mathrm{pH}$ optimum 7,5 - 8,5 (Hibban, 2016 dalam Pribadi et al., 2016). Sedangkan untuk aktivitas mikroorganisme pengurai biasanya terjadi dalam suhu yang hangat atau berada pada rentangan suhu optimum yang berkisar $20^{\circ} \mathrm{C}-30^{\circ} \mathrm{C}$ (Effendi, 2003 dalam Pribadi et al., 2016).

b) Kelebihan dan Kekurangan Proses Biofilter

Berdasarkan hasil review, ditemukan kelebihan dari pengolahan dari biofilter. Kelebihan dari menggunakan sistem biofilter adalah biaya yang murah dikarenakan media yang dipergunakan sebagai media memiliki harga yang terjangkau dipasaran, dan mudah ditemukan. Kekurangan dari proses biofilter adalah perlunya memperhatikan waktu kontak air limbah dengan mikroorganisme yang melekat pada media, pengontrolan terhadap konsentrasi pada inlet dan juga loading rate untuk tetap menjaga kestabilan proses pengolahan. Penelitian yang di-review kebanyakan menggunakan aerasi untuk meningkatkan
DO selama proses pengolahan dalam reaktor.

\section{Penambahan Zat Kimia}

a) Proses Penyisihan Amonia

Berdasarkan hasil review, ditemukan dua buah artikel yang menggunakan penambahan zat kimia sebagai metode penyisihan amonia. Cruz et al. (2018) menggunakan senyawa kimia yang bernama poly acrylic acid (PAA). PAA dipilih berdasarkan fungsinya yaitu PAA yang mengandung asam karboksilat terbukti memiliki afinitas pengikatan tinggi untuk $\mathrm{NH}_{4}{ }^{+}$di dalam larutan yang encer. Selain memapuan mengikat $\mathrm{NH}_{4}{ }^{+}$dapat terionisasi dan responsif terhadap $\mathrm{pH}$. Dilihat dari karakteristik zat kimia yang dipergunakan, proses yang dilakukan dalam penelitian Cruz et al. (2018) adalah proses adsorbsi. Adsorbsi adalah suatu proses ketika molekul terlarut (adsorbat) dihilangkan dengan cara menempelkan adsorbat pada permukaan adsorben (Adany, 2017).

Maria \& Affan (2017) melakukan proses penyisihan amonia menggunakan kaporit yang tujuan penelitiannya untuk melihat pengaruh konsentrasi kaporit terhadap penurunan amonia $\left(\mathrm{NH}_{3}\right)$. Variasi dosis klorin yang diberikan adalah sebesar 2,5 ml/l, $5 \mathrm{ml} / \mathrm{l}, 7,5 \mathrm{ml} / 1$. Dosis klorin yang efektif untuk menurunkan kandungan amonia adalah sebesar 7,5 $\mathrm{ml} / \mathrm{l}$. Penambahan klorin pada air limbah disebut dengan khlorinasi. Khlorinasi atau penambahan klorin banyak dipergunakan pada pengolahan dan penyediaan air domestik, disamping itu sering juga 
digunakan pada air limbah yang telah diolah. Zat khlor merupakan zat pengoksidasi, oleh karena itu jumlah khlor yang dibutuhkan tergantung pada konsentrasi organik dan zat $\mathrm{NH}_{3}-\mathrm{N}$ dalam air yang diolah (Rahardjo, 2002).

b) Kelebihan dan Kekurangan

Penambahan Zat Kimia

Berdasarkan hasil literatur review mengenai penambahan zat kimia kedalam proses penyisihan amonia ditemukan kelebihan dari proses ini adalah penambahan zat kimia merupakan proses yang praktis untuk menurunkan amonia dengan efisiensi tinggi. Terdapat juga kekurangan dari proses ini adalah penambahan senyawa kimia PAA pada penelitian Cruz et al. (2018) belum diketahui efektifitasnya terhadap pengolahan limbah secara konvensional.

\section{SIMPULAN}

Berdasarkan hasil studi literatur atau literature review ditemukan empat jenis metode pengolahan limbah yang dapat diterapkan sebagai alternatif pengolahan pada IPAL Suwung terhadap penyisihan amonia. Adapun metode pengolahan tersebut yaitu metode pengolahan dengan constructed wetland, lumpur aktif, biofilter, dan pengolahan secara kimiawi dengan penambahan zat kimia. Rentang rata-rata efisiensi penyisihan amonia dari metode pengolahan yaitu $50 \%$ sampai dengan $>90 \%$. Dengan rentang konsentrasi inlet amonia yang masuk ke dalam reaktor adalah dari $0,45-98,43 \mathrm{mg} / \mathrm{l}$ dan dengan rentangan loading rate amonia yang masuk pada reaktor adalah dari $0,23-290 \mathrm{mg} /$ hari.

Setiap metode pengolahan limbah memiliki kekurangan dan kelebihan pada setiap pengaplikasiannya. Keberhasilan dari setiap metode pengolahan tidak terlepas dari faktor-faktor yang mempengaruhi proses pengolahan yang dapat mempengaruhi keberhasilan dari setiap metode pengolahan. Faktor yang mempengaruhi keberhasilan metode pengolahan dengan constructed wetland adalah suhu, $\mathrm{pH}$, mikroorganisme, HRT, jenis tanaman air, proses aklimatisasi, dan media tumbuh. Faktor yang mempengaruhi keberhasilan metode pengolahan lumpur aktif adalah mikroorganisme, aerasi, ratio $\mathrm{C} / \mathrm{N}, \mathrm{HRT}, \mathrm{SRT}, \mathrm{pH}$, dan suhu. Berikutnya faktor yang mempengaruhi keberhasilan metode pengolahan biofilter adalah mikroorganisme, suhu, $\mathrm{pH}$, proses aklimatisasi, media, HRT, dan laju aliran. Pengolahan yang terakhir adalah pengolahan dengan metode pengolahan secara kimiawi, adapun faktor keberhasilan yang mempengaruhi proses pengolahan adalah suhu, pH dan konsentrasi zat.

\section{SARAN}

Berdasarkan hasil literature review beberapa saran yang dapat penulis sampaikan adalah perlu adanya pengujian dengan kondisi lapangan terhadap masingmasing metode pengolahan limbah dengan metode constructed wetland, lumpur aktif, biofilter, dan pengolahan secara kimiawi sebelum diterapkan dengan skala yang 
sebenarnya. Hal tersebut karena hasil literature review merupakan hasil penelitian yang dilakukan dengan skala laboratorium, sehingga perlu adanya penyesuaian antara sistem pengolahan yang dirancang di laboratorium dengan yang diterapkan di lapangan.

\section{UCAPAN TERIMA KASIH}

Ucapan terima kasih penulis ucapkan kepada UPT PAL Suwung yang telah memberikan kesempatan untuk ikut serta membantu memberikan solusi terkait sistem pengolahan limbah, serta kepada dosen pembimbing yang telah banyak membantu selama proses penelitian.

\section{DAFTAR PUSTAKA}

Adisuasono, R. T., Wardana, I. W., \& Sutrisno, E. (2014). Penurunan Konsentrasi Amoniak Dalam Limbah Cair Domestikdengan Teknologikolam (Pond)-Biofilm Menggunakan Mediabiofilter Pipa Pvc Sarang Tawon Dan Bata Ringan. Teknik Lingkungan, 1-12.

Asela, E., K., H. S., \& Astuti, D. (2016). Keefektifan Metode Fitoremediasi Dengan Pemanfaatan Tanaman Eceng Gondok Untuk Menurunkan Kadar Amoniak Limbah Rumah Sakit PKU Muhammadiyah Surakarta. Publikasi Ilmiah, 5-14.

Ashwin, \& Ramakrishaniah, C. (2014). Determination Of Bio-Kinetic Parameters For Sequencing Batch Reactor type Sewage Treatment Plant. International Journal of Civil
Engineering Research and Development (IJCERD), 51 - 58.

Cruz, h., Luckman, P., Seviour, T., Verstraete, W., Laycock, B., \& Pikaar, I. (2018). Rapid removal of ammonium from domestic wastewater using polymer hydrogels. Scientific Reports, 1-6.

Dewi, N. M., Mahendra, M. S., \& Suyasa, I. B. (2014). Pengembangan Fitoremediasi Untuk Meningkatkan Kualitas Air Limbah Hasil Pengolahan Instalasi Pengolahan Air Limbah Suwung. Ecotrophic: Journal of Environmental Science, 54-61.

Faisal, Machdar, I., Muhammad, S., Onodera, T., Syutsubo, K., \& Ohashi, A. (2017). Unjuk Kerja Down-Flow Hanging Sponge (DHS) Bioreaktor Sebagai Secondary Treatment Untuk Pengolahan Limbah Domestik. Jurnal Litbang Industri, 11-19.

Hastuti, Y. P. (2011). Nitrifikasi dan Denitrifikasi di Tambak. Jurnal Akuakultur Indonesia, 89-98.

Hibban, M., Rezagama, A., \& Purwono. (2016). Studi Penurunan Konsentrasi Amonia Dalam Limbah Cair Domestik Dengan Teknologi Biofilter Aerobmedia Tubular Plastik Pada Awal Pengolahan. Jurnal Teknik Lingkungan, 1-9.

Hidayah, E. N., Djalalembah, A., Asmar, G. A., \& Cahyonugroho, O. H. (2018). Pengaruh Aerasi Dalam Constructed Wetland Pada Pengolahan Air limbah. Jurnal Ilmu Lingkungan, 155162. 
Imron, Sriyani, N., Dermiyati, Suroso, E., \& Yuwono, S. B. (2019). Fitoremediasi dengan Kombinasi Gulma Air Untuk Memperbaiki Kualitas Air Limbah Domestik. Jurnal Ilmu Lingkungan, 51-60.

Kiding, A., Khitimah, S., \& Linda, R. (2015). Karakterisasi dan Kepadatan Bakteri Nitrifikasi pada Tingkat Kematangan Tanah Gambut yang Berbeda di Kawasan Hutan Lindung Gunung Ambawang Kabupaten Kubu Raya. Protobiont, 17-21.

Lestari, d. E. (2012). Efektivitas Pengolahan Limbah Cair Dpmestik dengan Metode Rawa Buatan (Constructed Wetland). Makasar: UIN Alauddin Makassar.

Maria, \& Affan, A. (2017). Pengaruh Konsentrasi Klorin terhadap Penurunan Kadar Amoniak $\left(\mathrm{NH}_{3}\right)$ Pada Air Limbah Domestik. Jurnal Ilmu Kesehatan Masyarakat, 206-213.

Ningtias, B. C., Moersidik, S. S., Priadi, C. R., \& Said, N. I. (2018). Pengolahan Air Domestik Dengan AnoksikAerobik Moving Bed Biofilm Reactor (Studi Kasus: Penyisihan Amonia dan Karbon dalam Air Limbah Domestik). Jurnal Air Indonesia, 177-188.

Nourmohammadi, et al. (2013). Nitrogen Removal in a Full-Scale Domestic Wastewater Treatment Plant With Activated Sludge and Trickling Filter. Journal of Environmental and Public Health, 1-6.
Peng, L., Hua, Y., Cai, J., Zhao, J., Zhou, W., \& Zhu, D. (2013). Effect of Plants and temperature on nitrogen removal and microbiology in a pilotscale integrated vertical-flow wetland treating primary domestic wastewater. Elsevier, 285 - 290.

Pertiwi, M. S., \& Handajani, M. (2012). Pengaruh Variasi Substrat dan Organik Loading rate Pada Pembentukan Biogranular Aerob Dalam Sequencing Batch Reactor. Jurnal Teknik Lingkungan, 135-144.

Pribadi, R. N., Zaman, B., \& Purwono. (2016). Pengaruh Luas Penutupan Kiambang (Salvinia Molesta) terhadap Penurunan COD, Amonia, Nitrit, dan Nitrat Pada Limbah Cair Domestik (Grey Water) Dengan Sistem Kontinyu. Jurnal Teknik Lingkungan, 1-10.

Puspita, L., Ratnawati, E., Suryadiputra, I. N., \& Meutia, A. A. (2005). Lahan Basah Buatan di Indonesia. Bogor: Wetlands International..

Rahardjo, P. N. (2002). Bagian 1 - B Teknologi Pengolahan Limbah Cair Dengan Proses Kimia. Teknologi Pengolahan Limbah Cair Industri, 39 78.

Rarasari, D. G., Restu, I., \& Ernawati, N. (2019). Efektivitas Pengolahan Limbah Domestik di Instalasi. Journal of Marine and Aquatic Sciences, 153 - 163.

Reddy, K. R., Patrick, J., \& W, H. (1984). Nitrogen Transformations And Loss In Flooded Soil And Sediments. CRC 
Critical Reviews in Environmental Control 13, 273.

Romadhony, A., \& Sutrisno, j. (2013). Kinerja Constructed Wetland Dalam Menurunkan Kandungan Phospat (PO4) dan Ammonia (NH3) Pada Limbah Rumah Sakit. Jurnal Teknik Waktu, 22 - 28.

Saeed, T., \& Sun, G. (2012). A Review On Nitrogen And Organics Removal Mechanisms In Subsurface Flow Constructed Wetlands: Depency On Environmental Parameters, Operating Conditions And Supporting Media. Journal of Environmental Management, 429-448.

Said, N. I., \& Utomo, K. (2018). Pengolahan Air Limbah Domestik Dengan Proses Lumpur Aktif Yang Diisi Dengan Media Bioball. Jurnal Air Indonesia, 160-174.

Sarasdewi, et al. (2015). Pengaruh Laju Aliran Terhadap Penurunan Cemaran Instalasi Pengolahan Air Limbah Domestik Dengan Sistem Biofilter. Rekayasa dan Manajemen Agroindustri, 17-30.

Shelef, et al. (2013). Role of Plants in a Coonstructed Wetland: current and new perspective. water, 401-409.

Singh, J. (2013). Critical appraisal skills programme. Journal of Pharmacology and Pharmacotherapeutics, 76 - 77.

Smith, R., et al. (2013). Implementation of Solid Retention Time (SRT) Control in Wastewater. Xylem, 1-9.

Smyk, J., \& Ignatowichz, K. (2017). The Influence Of Molasses On Nitrogen
Removal In Wastewater Treatment With Activated Sludge. Journal Ecological Egineering, 199 - 203.

Sumantri, A., \& Cordova, M. R. (2011). Dampak Limbah Domestik Perumahan Skala Kecil Terhadap Kualitas Air Ekosistem Penerimanya dan Dampaknya Terhadap Kesehatan Masyarakat. JPSL, 127 134.

Suparno. (2016). Penentuan Kadar Amonia Di Perairan Teluk Lampung Dengan Spektrofotometer UV-VIS (Skripsi). Bandar Lampung: Fakultas Matematika dan Ilmu Pengetahuan Alam Universitas Lampung.

Susana, T. (2004). Sumber Polutan Nitrogen Dalam Air Laut. Oseana, 24 - 34.

Suswati, A. C., \& Wibisono, G. (2013). Pengolahan Limbah Domestik Dengan Teknologi Taman Tanaman Air (Constructed Wetlands). Indonesia Green Technology Journal, 70 - 78.

Sy, Salmariza., et al. (2017). Pengaruh Laju Alir Inlet Reaktor MSL Terhadap Reduksi BOD, COD, TSS, dan Minyak/Lemak Limbah Cair Industri Minyak Goreng. Litbang Industri, 41-51.

Tchobanoglous, et al. (2003). Wastewater Engineering Treatment and Reuse (Fourth Edition). New York: Metcalf \& Eddy.Inc. 